\title{
Raw milk from vending machines: Effects of boiling, microwave treatment, and refrigeration on microbiological quality
}

\author{
Patrizio Tremonte, ${ }^{*}$ Luca Tipaldi, ${ }^{*}$ Mariantonietta Succi, ${ }^{*}$ Gianfranco Pannella, $\dagger$ Luisa Falasca, ${ }^{*}$ \\ Valeria Capilongo, ${ }^{*}$ Raffaele Coppola, ${ }^{*}$ and Elena Sorrentino*1 \\ *Dipartimento di Agricoltura, Ambiente e Alimenti (Dep. A.A.A.), University of Molise, 86100 Campobasso, Italy \\ †Scuola di Scienze Agrarie, Forestali, Alimentari e Ambientali, University of Basilicata, 85100 Potenza, Italy
}

\begin{abstract}
In Italy, the sale of raw milk from vending machines has been allowed since 2004. Boiling treatment before its use is mandatory for the consumer, because the raw milk could be an important source of foodborne pathogens. This study fits into this context with the aim to evaluate the microbiological quality of 30 raw milk samples periodically collected (March 2013 to July 2013) from 3 vending machines located in Molise, a region of southern Italy. Milk samples were stored for $72 \mathrm{~h}$ at $4^{\circ} \mathrm{C}$ and then subjected to different treatments, such as boiling and microwaving, to simulate domestic handling. The results show that all the raw milk samples examined immediately after their collection were affected by high microbial loads, with values very close to or even greater than those acceptable by Italian law. The microbial populations increased during refrigeration, reaching after $72 \mathrm{~h}$ values of about 8.0 $\log \mathrm{cfu} / \mathrm{mL}$ for Pseudomonas spp., $6.5 \mathrm{log} \mathrm{cfu} / \mathrm{mL}$ for yeasts, and up to $4.0 \mathrm{log} \mathrm{cfu} / \mathrm{mL}$ for Enterobacteriaceae. Boiling treatment, applied after $72 \mathrm{~h}$ to refrigerated milk samples, caused complete decontamination, but negatively affected the nutritional quality of the milk, as demonstrated by a drastic reduction of whey proteins. The microwave treatment at $900 \mathrm{~W}$ for 75 s produced microbiological decontamination similar to that of boiling, preserving the content in whey proteins of milk. The microbiological characteristics of raw milk observed in this study fully justify the obligation to boil the raw milk from vending machines before consumption. However, this study also showed that domestic boiling causes a drastic reduction in the nutritional value of milk. Microwave treatment could represent a good alternative to boiling, on the condition that the process variables are standardized for safe domestic application.
\end{abstract}

Received November 21, 2013

Accepted February 11, 2014.

${ }^{1}$ Corresponding author: sorrentino@unimol.it
Key words: unpasteurized raw milk, food safety, boiling, microwave treatment

\section{INTRODUCTION}

In Italy, as well as in different industrialized countries, raw milk consumption is becoming rather popular, thanks to the current trend toward "consuming natural" and "purchasing locally." Enhanced nutritional qualities, taste, and health benefits are advocated as reasons for the increased interest in raw milk consumption (Oliver et al., 2009). Raw milk supporters claim the suitability of unpasteurized milk for the treatment or for the prevention of some diseases, even if no scientific evidence supports this notion (Oliver et al., 2005). Only few epidemiological studies suggest that earlylife exposure to unpasteurized milk could reduce the risk for developing asthma, allergic rhinitis, hay fever, pollen allergy, and atopic sensitization (Barnes et al., 2001; Waser et al., 2007; Loss et al., 2011).

It is a widespread belief that heating destroys the nutritional and health benefits of milk, but it is as important to underscore that raw milk can harbor a variety of microorganisms and it could be an important source of foodborne pathogens, such as Salmonella spp., Campylobacter spp., Escherichia coli, and Listeria monocytogenes, among others (Hill et al., 2012; Claeys et al., 2013; Serraino et al., 2013). The presence of pathogenic bacteria in raw milk is well documented: in Italy, several studies on raw milk collected from vending machines detected the presence of different pathogens, such as Salmonella spp., E. coli O157:H7, Campylobacter spp. and L. monocytogenes (Giacometti et al., 2012a; Bianchi et al., 2013; Serraino et al., 2013); in the United States and in Ireland, some cases of listeriosis due to the consumption of raw milk were recently described (Latorre et al., 2011; Hunt et al., 2012); in Canada, an outbreak due to the presence of $E$. coli in dairy products made from raw milk was reported (Gaulin et al., 2012).

In Italy, the sale of raw milk through vending machines has been allowed since 2004. Specific norms for both milk quality and characteristics of vending ma- 
chines have been imposed (EU, 2004; Italian Republic, 2007). Moreover, the Italian law imposed the restriction on users to store raw milk at $4^{\circ} \mathrm{C}$ for a maximum period of $72 \mathrm{~h}$. After several episodes of hemolytic-uremic syndrome in children associated with the consumption of raw milk, the Italian Ministry of Health (2009) published the ordinance that obliges the posting on vending machines of the prominent notice "Milk must be boiled before consumption." Moreover, in the light of the latest scientific evidence (Scavia et al., 2009), in 2013, the Italian Ministry of Health reiterated the need to consume the raw milk after boiling.

In a previous study, Sorrentino et al. (2012) highlighted that refrigeration applied to raw milk during storage in vending machines is not a guarantor of microbiological safety, as some contaminating species are able to multiply at low temperatures. Furthermore, improper handling of milk by consumers may further increase the risk of contamination; in fact, Giacometti et al. (2012b) reported that $82 \%$ of consumers do not use insulated bags to transport raw milk home and the transport time often exceeds $30 \mathrm{~min}$.

Boiling, as imposed by the Italian Ministry of Health (2009, 2013), remains the sole method to ensure the safety of milk. However, the responsibility of hygienic sanitation of raw milk is actually given to the consumer, who often underestimates or completely ignores the risk associated with raw milk consumption (D'Ascenzi et al., 2010; Giacometti et al., 2012b).

This study fit into this context with different aims: to evaluate the microbiological quality and safety of raw milk collected from different vending machines located in the Molise region, to study the quantitative variations in microbial populations of raw milk during storage at $4^{\circ} \mathrm{C}$ for $72 \mathrm{~h}$, and to assess the effect of a domestic boiling process and of different microwave treatments on the safety and the quality of milk.

\section{MATERIALS AND METHODS}

\section{Experimental Design and Milk Treatments}

Raw milk samples were aseptically collected from March 2013 to July 2013 in 3 different vending machines located in the Molise Region (Southern Italy). Each month, 2 different samples were collected from each vending machine, and a total of 30 raw milk samples were obtained. At the time of sampling, the temperature of the milk was measured. All the samples were placed in a cool box, stored at $4.0 \pm 0.5^{\circ} \mathrm{C}$ until delivery to the laboratory (Dipartimento di Agricoltura, Ambiente e Alimenti, University of Molise, Campobasso, Italy), and analyzed within $2 \mathrm{~h}$ after sampling. The samples from each vending machine, collected in different periods, were divided into 10 batches:
- $\mathrm{C}_{0}$ : untreated raw milk subjected to analysis immediately after its delivery to the laboratory;

- $\mathrm{C}_{24}$ : untreated raw milk subjected to analysis after $24 \mathrm{~h}$ of storage at $4.0 \pm 0.5^{\circ} \mathrm{C}$;

- $\mathrm{C}_{48}$ : untreated raw milk subjected to analysis after $48 \mathrm{~h}$ of storage at $4.0 \pm 0.5^{\circ} \mathrm{C}$;

- $\mathrm{C}_{72}$ : untreated raw milk subjected to analysis after $72 \mathrm{~h}$ of storage at $4.0 \pm 0.5^{\circ} \mathrm{C}$;

- $\mathrm{B}_{0}$ : raw milk subjected to a simulated domestic boiling treatment immediately after its delivery to the laboratory;

- $\mathrm{B}_{24}$ : raw milk stored at $4.0 \pm 0.5^{\circ} \mathrm{C}$ for $24 \mathrm{~h}$ and then subjected to a simulated domestic boiling treatment;

- $\mathrm{B}_{48}$ : raw milk stored at $4.0 \pm 0.5^{\circ} \mathrm{C}$ for $48 \mathrm{~h}$ and then subjected to a simulated domestic boiling treatment;

- $\mathrm{B}_{72}$ : raw milk stored at $4.0 \pm 0.5^{\circ} \mathrm{C}$ for $72 \mathrm{~h}$ and then subjected to a simulated domestic boiling treatment;

- $\mathrm{M}_{750}$ : raw milk subjected to a simulated domestic microwave treatment at $750 \mathrm{~W}$ for $75 \mathrm{~s}$ immediately after its delivery to the laboratory;

- $\mathrm{M}_{900}$ : raw milk subjected to a simulated domestic microwave treatment at $900 \mathrm{~W}$ for $75 \mathrm{~s}$ immediately after its delivery to the laboratory.

To simulate a domestic boiling treatment, $200 \mathrm{~mL}$ (approximately a capful) of raw milk from the B batches was poured into a small, previously sterilized pan and heated until the appearance of foam. The treatment was immediately stopped, and analyses were carried out within 15 min. During boiling, the milk temperature was monitored using a digital thermometer (Delta Ohm S.r.L., Padua, Italy).

To simulate domestic microwave treatment, 200 $\mathrm{mL}$ (approximately a capful) of raw milk from the $\mathrm{M}$ batches was poured into a sterilized 300-mL Pyrex beaker and the treatment was performed by using a domestic microwave oven with $950-\mathrm{W}$ nominal output at 2,450 MHz (Whirlpool FT380; Whirlpool Europe Srl, Comerio, Italy). Two different programs were used: $750 \mathrm{~W}$ for $75 \mathrm{~s}$ and $900 \mathrm{~W}$ for $75 \mathrm{~s}$. Immediately after treatments, the milk temperature was monitored as described above.

\section{Microbiological Analyses}

For microbial counts, raw and treated milk samples from each batch were serially diluted using $0.1 \%$ peptone water. The different microbial groups were detected on specific media and incubation temperatures. In detail, total mesophilic count (TMC) was performed on plate count agar (Oxoid Ltd., Basingstoke, UK) incubated 
at $30 \pm 1^{\circ} \mathrm{C}$ for $72 \pm 3 \mathrm{~h}$ (UNI EN ISO, 2004); yeast extract-peptone-dextrose (YPD) agar plates (10 g of yeast extract/L, $20 \mathrm{~g}$ of bacteriological peptone/L, $20 \mathrm{~g}$ of dextrose/L, and $20 \mathrm{~g}$ of agar/L), prepared as previously described by Reale et al. (2011), were used to detect yeasts after incubation at $28 \pm 1^{\circ} \mathrm{C}$ for $72 \pm 2$; lactic acid bacteria (LAB) were counted on de Man, Rogosa, and Sharpe (MRS) agar (Oxoid Ltd.) incubated at $28 \pm 1^{\circ} \mathrm{C}$ for $48 \pm 2 \mathrm{~h}$ in anaerobic conditions (BBL GasPak Anaerobic System; Becton Dickinson, Franklin Lakes, NJ); enterococci were recognized on Slanetz and Bartley medium (Oxoid Ltd.) incubated at $37 \pm 1^{\circ} \mathrm{C}$ for $48 \pm 2 \mathrm{~h}$; Enterobacteriaceae were detected in violet red bile glucose agar (Oxoid Ltd.) incubated at $37 \pm$ $1^{\circ} \mathrm{C}$ for $24 \pm 1 \mathrm{~h}$ (ISO, 2004); total and fecal coliforms were differentiated on violet red bile lactose agar (VRBLA; Oxoid Ltd.) incubated for $36 \mathrm{~h}$ at $37 \pm 1$ and $44 \pm 1^{\circ} \mathrm{C}$, respectively; the presence of Pseudomonas spp. was highlighted on Pseudomonas agar base (Oxoid Ltd.) supplemented with cephalothin-sodium fusidatecetrimide (CFC) Pseudomonas selective supplement (Oxoid Ltd.) after incubation at $25 \pm 1^{\circ} \mathrm{C}$ for $48 \pm 2 \mathrm{~h}$; and micrococci and staphylococci were determined on mannitol salt agar (Oxoid Ltd.) incubated at $28 \pm 1{ }^{\circ} \mathrm{C}$ for $48 \pm 2 \mathrm{~h}$.

Analyses were performed in duplicate and the results were expressed as the logarithm of colony-forming units per milliliter of milk.

\section{Chemical Analyses}

Whey proteins were determined as the difference between noncasein nitrogen 155 and NPN and expressed as a percentage of total protein in milk. Noncasein nitrogen was determined by the Kjeldahl method after casein precipitation at $\mathrm{pH} 4.6$ and NPN was determined by the Kjeldahl method after precipitation with TCA according to Resmini et al. (1985). Total protein content was determined by the Kjeldahl method, following the Italian official method (Italian Republic, 1992). The $\mathrm{pH}$ value of each sample was measured using a $\mathrm{pH}$ meter (Crison Instruments SA, Barcelona, Spain).

The qualitative detection of alkaline phosphatase and lactoperoxidase in whole milk samples was performed using the Lactognost kit (Heyl Chemischpharmazeutische Fabrik GmbH \& Co. KG, Berlin, Germany) and the Perossitest kit (Astori Tecnica s.n.c., Poncarale, Italy), respectively.

\section{Statistical Analyses}

An ANOVA was applied to the data. The least significant differences were obtained using a least significant difference test $(P<0.05)$. Statistical analysis was performed using SPSS software (version 13.0 for Windows; SPSS Inc., Chicago, IL).

\section{RESULTS AND DISCUSSION}

At the time of sampling, the milk temperature ranged from 3.5 to $4.1^{\circ} \mathrm{C}$ (data not shown), in line with the Italian legislation. No significant difference was highlighted among temperatures recorded in the different vending machines during the entire period of this study (March 2013 to July 2013). All the raw milk samples collected from vending machines showed a positive result for alkaline phosphatase and lactoperoxidase tests, and a content of whey proteins/total proteins ranging from 19.9 to $18.7 \%$ was highlighted, thus confirming that milk was not heat treated. The initial $\mathrm{pH}$ value $\left(\mathrm{C}_{0}\right)$ was $6.72 \pm 0.06$, and no significant differences $(P>$ 0.05 ) were found among milk samples withdrawn from the different vending machines (data not shown). During storage in the refrigerator $\left(4.0 \pm 0.5^{\circ} \mathrm{C}\right), \mathrm{pH}$ values progressively decreased up to $6.27 \pm 0.04$ at $72 \mathrm{~h}\left(\mathrm{C}_{72}\right)$, as a consequence of microbial growth. In fact, some microbial groups increased in number during storage, as illustrated in Figure 1. Specifically, mesophilic bacteria were initially present with total counts of about $5.0 \mathrm{log}$ $\mathrm{cfu} / \mathrm{mL}$, the maximum level acceptable by the Italian regulation (Italian Republic, 2007), or higher. In fact, out of 30 samples from batch $\mathrm{C}_{0}, 11$ showed a microbial load very close to $5.0 \log \mathrm{cfu} / \mathrm{mL}, 9$ exhibited a load slightly lower than $5.0 \log \mathrm{cfu} / \mathrm{mL}$, and the remaining 10 samples evidenced counts over $5.0 \log \mathrm{cfu} / \mathrm{mL}$, independent of the vending machine and the period of collection. These data are in agreement with those found by Giacometti et al. (2012a). The TMC was also determined after refrigeration for 24,48 , and $72 \mathrm{~h}$ at $4.0 \pm 0.5^{\circ} \mathrm{C}$ (Figure 1), as raw milk can be preserved in home refrigerators for a maximum period of $72 \mathrm{~h}$. During storage, an increase in TMC was observed and after $72 \mathrm{~h}\left(\mathrm{C}_{72}\right)$, a significant increase $(P<0.05)$ was detected in all samples.

As for the different microbial groups, Pseudomonas spp. showed the highest counts already at time zero $(5.0 \log \mathrm{cfu} / \mathrm{mL})$ and counts significantly increased $(P<0.05)$, reaching about $8.0 \log \mathrm{cfu} / \mathrm{mL}$ after $72 \mathrm{~h}$ $\left(\mathrm{C}_{72}\right)$ of storage. Yeasts and LAB showed an increase of about $1.5 \mathrm{log} \mathrm{cfu} / \mathrm{mL}$ during storage, starting from values of about $5.0 \log \mathrm{cfu} / \mathrm{mL}\left(\mathrm{C}_{0}\right)$ for yeasts and of about $4.0 \mathrm{log} \mathrm{cfu} / \mathrm{mL}$ for LAB. Enterobacteriaceae and total coliforms showed initial values $\left(\mathrm{C}_{0}\right)$ lower than 3.0 $\log \mathrm{cfu} / \mathrm{mL}$, and after $72 \mathrm{~h}\left(\mathrm{C}_{72}\right)$, counts increased up to about 4.0 and $3.5 \log \mathrm{cfu} / \mathrm{mL}$, respectively. Counts lower than $3.0 \log \mathrm{cfu} / \mathrm{mL}$ were detected for all other microbial groups (Figure 1). 


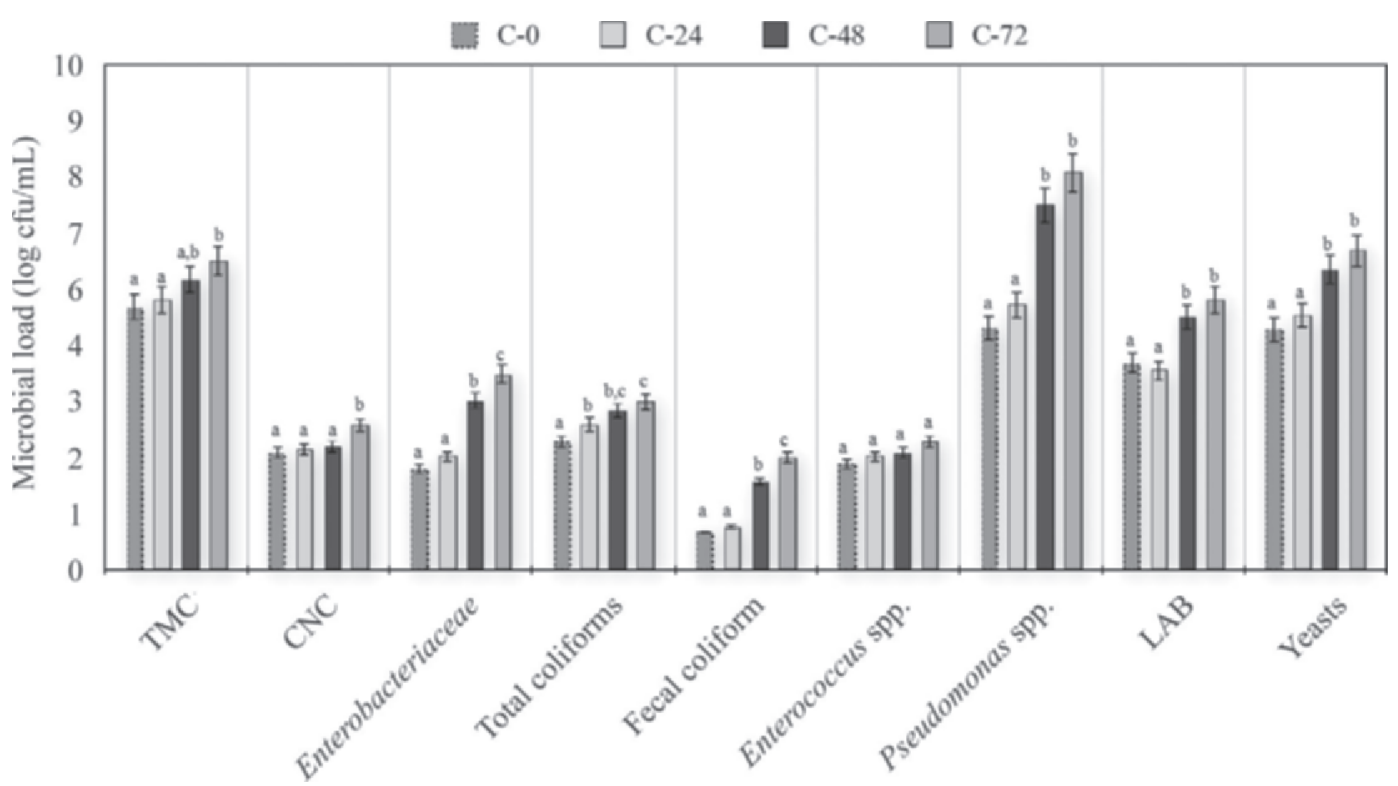

Figure 1. Average values of microbial loads determined in raw milk (log cfu/mL) at time zero and after 24,48 , and $72 \mathrm{~h}$ of storage at 4 $\pm 0.5^{\circ} \mathrm{C}$. Different letters $(\mathrm{a}-\mathrm{c})$ at the same microbial group indicate significant differences $(P<0.05)$. C- $0=$ untreated raw milk subjected to analysis immediately after its delivery to the laboratory; C-24, C-48, and C-72 = untreated raw milk subjected to analysis after 24,48 , and $72 \mathrm{~h}$ of storage at $4.0 \pm 0.5^{\circ} \mathrm{C}$, respectively; $\mathrm{TMC}=$ total mesophilic count; $\mathrm{CNC}=$ coagulase-negative cocci; LAB $=$ lactic acid bacteria. The error bars represent the SD calculated on 30 samples collected from 3 different vending machines at different sampling times.

Data reported above confirm that raw milk from vending machines can be contaminated by a variety of microorganisms (Oliver et al., 2009) and, in some cases, the microbial load exceeded that acceptable by the Italian regulation (Italian Republic, 2007). Some microbial groups showed the ability to grow at $4^{\circ} \mathrm{C}$; these data deserve some attention, considering the fact that home refrigerators frequently are at temperatures above $4^{\circ} \mathrm{C}$ (Godwin et al., 2007), thus allowing higher microbial proliferation during storage than that described in this study. Moreover, during refrigeration of milk, some microorganisms can produce harmful heat-stable enterotoxins (Caballero Gómez et al., 2013) or enzymes capable of degrading or modifying milk nutrients, such as fat-soluble vitamins, thus lowering the nutritional value of raw milk (Panfili et al., 2008). These considerations increase the elements of doubt regarding the safety of raw milk and its nutritional value after storage at $4^{\circ} \mathrm{C}$ for $72 \mathrm{~h}$. Also, it is important to underscore that many consumers not only disregard the requirement to boil the raw milk from vending machines, but also they frequently give raw milk to children (D'Ascenzi et al., 2010; Giacometti et al., 2012b), although in Italy, it is mandatory to boil raw milk before consumption.

Thus, the subsequent step in this study was to boil the raw milk, as imposed by the Italian Ministry of Health (2013). Because no specification is given as to the suitable time to apply the heat treatment, it was performed before refrigeration (time 0 ), as well as at different refrigeration times $(24,48$, and $72 \mathrm{~h})$. Each boiling, performed simulating domestic handling as described above, was stopped at the appearance of foam (i.e., when the milk temperature reached about $95^{\circ} \mathrm{C}$ ). Data reported in Figures $2 \mathrm{a}, 2 \mathrm{~b}, 2 \mathrm{c}$ and $2 \mathrm{~d}$ show that boiling effectively sanitized the milk. In fact, all samples after boiling were characterized by undetectable microbial counts. As expected, both alkaline phosphatase and lactoperoxidase tests gave negative results in all treated milk samples due to severe heating. As the content in whey proteins is routinely used to assess the thermal damage in milk (Sorrentino et al., 2005), the effect of boiling treatment on this parameter was also ascertained (Figure 3). The determination was performed only on raw milk samples (batch $\mathrm{C}_{0}$ ) and on milk samples boiled at time 0 (batch $\mathrm{B}_{0}$ ), as microbial growth does not influence the ratio of whey proteins to total proteins in raw milk stored at $4^{\circ} \mathrm{C}$ (Miralles et al., 2000). The results highlight that in milk subjected to boiling, the whey protein ratio in total protein (\%) decreased to values of approximately $4.3 \pm 0.35 \%$, starting from values of $19.3 \pm 0.6 \%$ in raw milk. Therefore, the boiling caused a drastic depletion of the soluble-protein component, as a consequence of severe thermal damage (Morales et al., 2000), hence rendering raw milk characteristics very different from those of pasteurized milk.

Despite previous results not encouraging raw milk consumption, it is important to take into account con- 

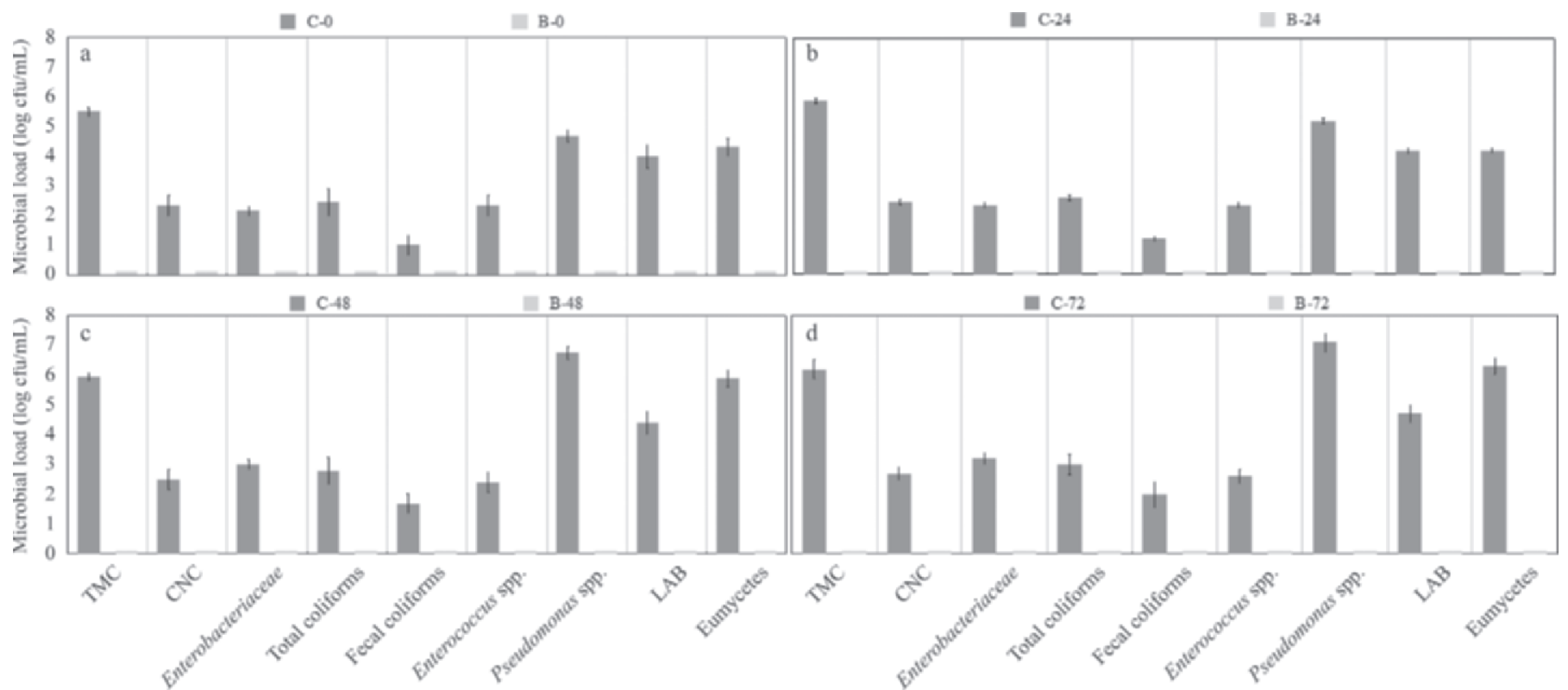

Figure 2. (a) Microbial counts of raw milk upon arrival at the laboratory (C-0) and immediately boiled (B-0). (b), (c), and (d) Levels of microbial loads determined in raw milk stored at $4 \pm 0.5^{\circ} \mathrm{C}$, respectively, for 24 (C-24), 48 (C-48), and $72 \mathrm{~h}(\mathrm{C}-72)$ and in the milk subjected to boiling after the period of cold storage (designated as B-24, B-48, and B-72, respectively). TMC = total mesophilic count; CNC = coagulasenegative cocci; LAB = lactic acid bacteria. The error bars represent the SD calculated on 30 samples collected from 3 different vending machines at different sampling times.

sumer preference for this product. Moving from this assumption, the identification of a proper domestic decontaminating treatment, as an alternative to boiling, was a further aim of this study. Specifically, the effect of different microwave treatments on the safety and the nutritional features of raw milk were evaluated. The

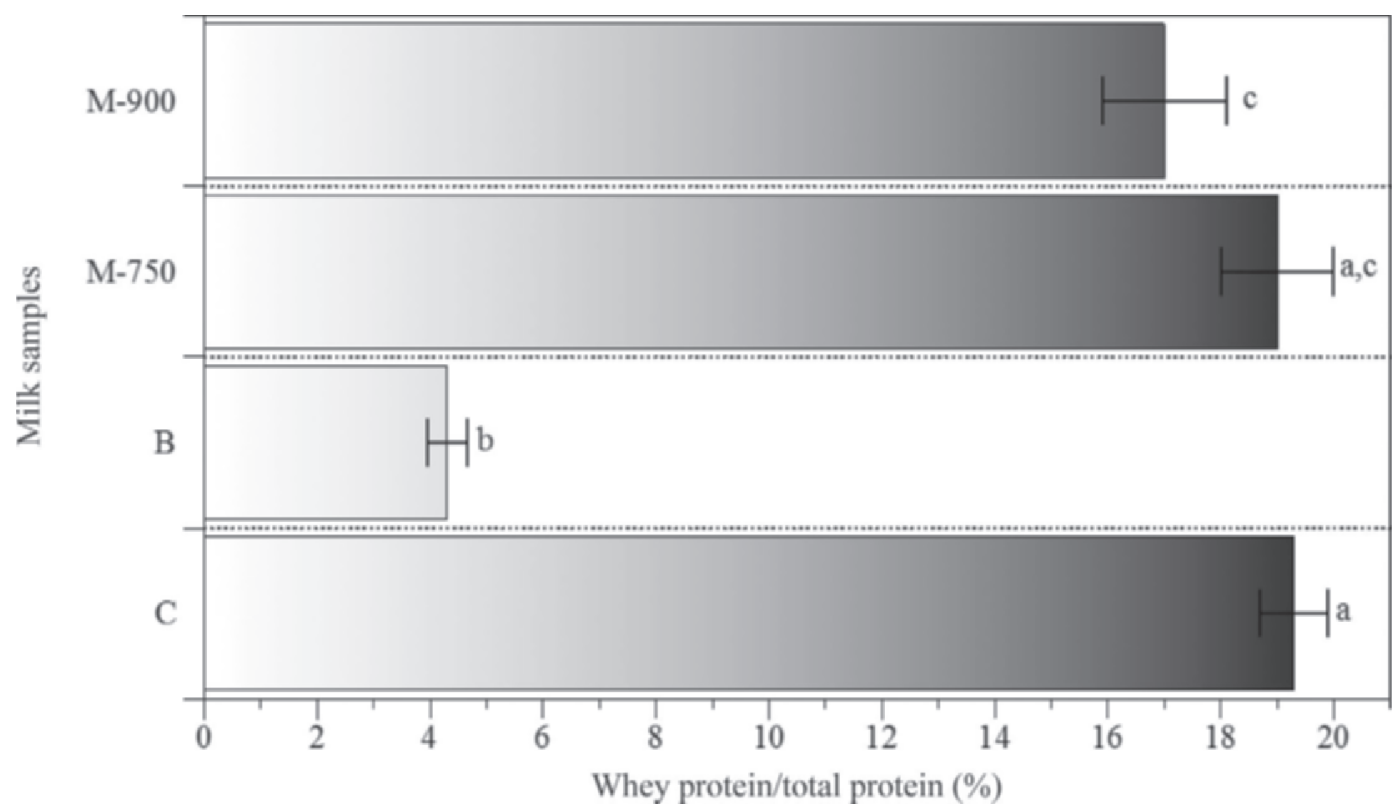

Figure 3. Whey protein in samples of raw milk (C), in boiling milk (B), and in milk treated in a microwave oven $\left(\mathrm{M}_{750}\right.$ and $\mathrm{M}_{900}$, indicating that raw milk was subjected to microwave treatment at 750 and $900 \mathrm{~W}$, respectively, for $75 \mathrm{~s}$ immediately after its delivery to the laboratory). Different letters $(\mathrm{a}-\mathrm{c})$ indicate significant differences $(P<0.05)$. The error bars represent the SD calculated on 30 samples collected from 3 different vending machines at different sampling times. 


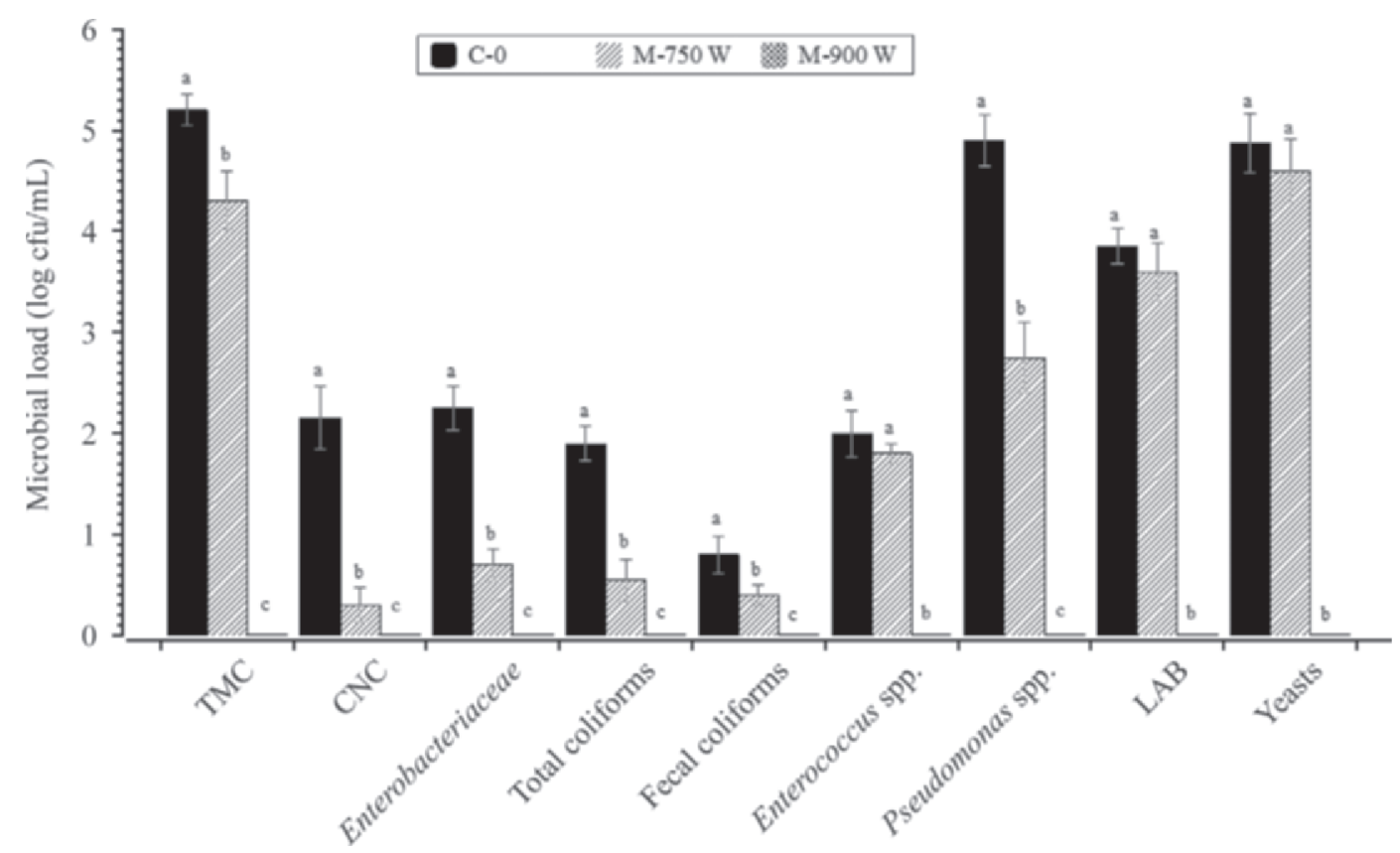

Figure 4. Microbial counts of raw milk upon arrival at the laboratory (C-0) and after microwave treatment at $750 \mathrm{~W}$ (M-750 W) and at 900 $\mathrm{W}(\mathrm{M}-900 \mathrm{~W})$ for $75 \mathrm{~s}$. Different letters $(\mathrm{a}-\mathrm{c})$ at the same microbial group indicate significant differences $(P<0.05)$. TMC $=$ total mesophilic count; $\mathrm{CNC}=$ coagulase-negative cocci; $\mathrm{LAB}=$ lactic acid bacteria. The error bars represent the SD calculated on 30 samples collected from 3 different vending machines at different sampling times.

microwave treatment was performed using a sterilized 300-mL Pyrex beaker to ensure replicable treatments, as the geometry, material, and color of the vessel have great influence on the temperature distribution inside the vessel.

Data highlighted that the treatment at $750 \mathrm{~W}$ for 75 $\mathrm{s}\left(\mathrm{M}_{750}\right)$ caused a reduction of about $2.0 \mathrm{log} \mathrm{cfu} / \mathrm{mL}$ for Enterobacteriaceae, total coliforms and Pseudomonas spp., and of about $1.0 \mathrm{log} \mathrm{cfu} / \mathrm{mL}$ for TMC and enterococci (Figure 4). Fecal coliforms, LAB, and yeasts showed a lower sensitivity to the applied treatment, thus allowing only partial microbiological sanitation of the milk. The application of $900 \mathrm{~W}$ for $75 \mathrm{~s}\left(\mathrm{M}_{900}\right)$ resulted in effective microbiological sanitation, comparable with boiling, as evidenced by undetectable microbial counts after the treatment (Figure 4). Moreover, after the microwave treatments, the alkaline phosphatase test was negative and the peroxidase test was positive in all milk samples from both batches $\mathrm{M}_{750}$ and $\mathrm{M}_{900}$. As for the content in whey proteins, values of about $18.5 \pm 0.7$ and $16.5 \pm 0.4 \%$ were found in samples from batches $\mathrm{M}_{750}$ and $\mathrm{M}_{900}$, respectively (Figure 3).

The results described above suggest that the microwave treatment of raw milk could be an excellent alternative to boiling, because it is able to ensure the hygienic quality of milk, preserving its nutritional features. However, the strong influence of the vessel as well as the lack of information regarding the sensitivity of pathogens and their toxins to microwave treatments require further studies before suggesting microwaving in place of boiling.

\section{CONCLUSIONS}

In Italy, raw milk sale from vending machines is an alternative to consumption of pasteurized milk. However, in light of the results obtained in this and in other similar studies, it has emerged that unpasteurized raw milk could represent a health hazard, taking into account not only the ability of some microbial groups to grow at refrigeration temperatures, but also the hazardous habit of many consumers to drink raw milk without preliminary heat treatment. Boiling treatment is currently the optimal solution to ensure the hygienic quality of raw milk. On the other hand, this treatment impoverishes the nutritional value of raw milk, effectively distorting the elements behind the success of this product. Microwaving could be an excellent alternative to boiling, as it guarantees the hygienic quality of milk, preserving the nutritional features. However, further studies are required to identify and standardize the process variables and to guarantee safe domestic handling. Consumption of raw milk from vending machines can hardly be justified from a rational or scientific point of view. 


\section{REFERENCES}

Barnes, M., P. Cullinan, P. Athanasaki, S. MacNeill, A. M. Hole, J. Harris, S. Kalogeraki, M. Chatzinikolaou, N. Drakonakis, V. Bibaki-Liakou, A. J. N. Taylor, and I. Bibakis. 2001. Crete: Does farming explain urban and rural differences in atopy? Clin. Exp. Allergy 31:1822-1828.

Bianchi, D. M., A. Barbaro, S. Gallina, N. Vitale, L. Chiavacci, M. Caramelli, and L. Decastelli. 2013. Monitoring of foodborne pathogenic bacteria in vending machine raw milk in Piedmont, Italy. Food Contr. 32:435-439.

Caballero Gómez, N., H. Abriouel, M. J. Grande, R. P. Pulido, and A. Gálvez. 2013. Combined treatments of enterocin AS-48 with biocides to improve the inactivation of methicillin-sensitive and methicillin-resistant Staphylococcus aureus planktonic and sessile cells. Int. J. Food Microbiol. 163:96-100.

Claeys, W. L., S. Cardoen, G. Daube, J. De Block, K. Dewettinck, K. Dierick, L. De Zutter, A. Huyghebaert, H. Imberechts, P. Thiange, Y. Vandenplas, and L. Herman. 2013. Raw or heated cow milk consumption: Review of risks and benefits. Food Contr. 31:251-262.

D'Ascenzi, C., F. Pedonese, L. Nicodemi, R. Nuvoloni, F. Forzale, and S. Rindi. 2010. Efficacia della gestione del rischio nella vendita diretta di latte crudo presso il centro "E. Avanzi" dell'Università di Pisa. Ital. J. Food Safety 7:30-35.

EU (European Union). 2004. Regulation (EC) No. 853/2004 of the European Parliament and of the Council of 29 April 2004 laying down specific hygiene rules on the hygiene of foodstuffs. Official Journal, L139, 30.4.2004.

Gaulin, C., E. Levac, D. Ramsay, R. Dion, J. Ismail, S. Gingras, and C. Lacroix. 2012. Escherichia coli O157:H7 outbreak linked to raw milk cheese in Quebec, Canada: Use of exact probability calculation and case-case study approaches to foodborne outbreak investigation. J. Food Prot. 75:812-818.

Giacometti, F., A. Serraino, G. Finazzi, P. Daminelli, M. N. Losio, N. Arrigoni, S. Piva, D. Florio, R. Riu, and R. G. Zanoni. 2012a. Sale of raw milk in Northern Italy: Food safety implications and comparison of different analytical methodologies for detection of foodborne pathogens. Foodborne Pathog. Dis. 9:293-297.

Giacometti, F., A. Serraino, G. Finazzi, P. Daminelli, M. N. Losio, M. Tamba, A. Garigliani, R. Mattioli, R. Riu, and R. G. Zanoni. 2012b. Field handling conditions of raw milk sold in vending machines: Experimental evaluation of the behaviour of Listeria monocytogenes, Escherichia coli O157:H7, Salmonella Typhimurium and Campylobacter jejuni. Ital. J. Anim. Sci. 11:132-136.

Godwin, S. L., F. C. Chen, E. Chambers IV, R. Coppings, and D. Chambers. 2007. A comprehensive evaluation of temperature within home refrigerators. Food Protect. Trends 27:16-21.

Hill, B., B. Smythe, D. Lindsay, and J. Shepherd. 2012. Microbiology of raw milk in New Zealand. Int. J. Food Microbiol. 157:305-308.

Hunt, K., N. Drummond, M. Murphy, F. Butler, J. Buckley, and K. Jordan. 2012. A case of bovine raw milk contamination with Listeria monocytogenes. Ir. Vet. J. 65:13.

ISO (International Organization for Standardization). 2004. Microbiology of food and animal feeding stuffs - Horizontal methods for the detection and enumeration of Enterobacteriaceae - Part 2: Colonycount method. ISO 21528-2:2004. ISO, Geneva, Switzerland.

Italian Ministry of Health. 2009. Misure urgenti in materia di produzione, commercializzazione e vendita diretta di latte crudo per l'alimentazione umana. Italian Official Journal no. 10,14/01/2009. Italian Ministry of Health, Rome, Italy.

Italian Ministry of Health. 2013. Disposizioni urgenti per promuovere lo sviluppo del Paese mediante un più alto livello di tutela della salute. Italian Official Journal no. 24, 29/1/2013. Italian Ministry of Health, Rome, Italy.

Italian Republic. 1992. Metodi di analisi e di prove del latte trattato termicamente destinato al consumo umano diretto. Official Journal no. 407, 31/12/1992.

Italian Republic. 2007. Permanent Council State-Regions and Autonomous Provinces. Accordo Stato - Regioni e Province Auto- nome 25-1-2007. In materia di vendita diretta di latte crudo per l'alimentazione umana. Official Journal no. 36 13/2/2007.

Latorre, A. A., A. K. Pradhan, J. A. Van Kessel, J. S. Karns, K. J. Boor, D. H. Rice, K. J. Mangione, Y. T. Gröhn, and Y. H. Schukken. 2011. Quantitative risk assessment of Listeriosis due to consumption of raw milk. J. Food Prot. 74:1268-1281.

Loss, G., S. Apprich, M. Waser, W. Kneifel, J. Genuneit, G. Büchele, J. Weber, B. Sozanska, H. Danielewicz, E. Horak, R. J. J. van Neerven, D. Heederik, P. C. Lorenzen, E. von Mutius, C. BraunFahrländer, and the GABRIELA study group. 2011. The protective effect of farm milk consumption on childhood asthma and atopy: The GABRIELA study. J. Allergy Clin. Immunol. 128:766-773.

Miralles, B., B. Bartolomé, M. Ramos, and L. Amigo. 2000. Determination of whey protein to total protein ratio in UHT milk using fourth derivative spectroscopy. Int. Dairy J. 10:191-197.

Morales, F.-J., C. Romero, and S. Jiménez-Pérez. 2000. Characterization of industrial processed milk by analysis of heat-induced changes. Int. J. Food Sci. Technol. 35:193-200.

Oliver, S. P., K. J. Boor, S. C. Murphy, S. C. Murphy, and S. E. Murinda. 2009. Food safety hazards associated with consumption of raw milk. Foodborne Pathog. Dis. 6:793-806. http://dx.doi. org/10.1089/fpd.2009.0302.

Oliver, S. P., B. M. Jayarao, and R. A. Almeida. 2005. Foodborne pathogens in milk and dairy farm environment: Food safety and public health implications. Foodborne Pathog. Dis. 2:115-129.

Panfili, G., A. Fratianni, T. Di Criscio, D. Gammariello, and E. Sorrentino. 2008. Influence of microorganisms on retinol isomerization in milk. J. Dairy Res. 75:37-43. http://dx.doi.org/10.1017/ S0022029907003044.

Reale, A., T. Di Renzo, M. Succi, P. Tremonte, R. Coppola, and E. Sorrentino. 2011. Identification of lactobacilli isolated in traditional ripe wheat sourdoughs by using molecular methods. World J. Microbiol. Biotechnol. 27:237-244. http://dx.doi.org/10.1007/ s11274-010-0448-x.

Resmini, P., C. Tripiciano, M. Rampilli, and R. Lodi. 1985. Alcuni aspetti del controllo qualità del latte al consumo. Riv. Soc. It. Sci. Alim. 3:187-196.

Scavia, G., M. Escher, F. Baldinelli, C. Pecoraro, and A. Caprioli. 2009. Consumption of unpasteurized milk as a risk factor for hemolytic uremic syndrome in Italian children. Clin. Infect. Dis. 48:1637-1638.

Serraino, A., D. Florio, F. Giacometti, S. Piva, D. Mion, and R. G. Zanoni. 2013. Presence of Campylobacter and Arcobacter species in in-line milk filters of farms authorized to produce and sell raw milk and of a water buffalo dairy farm in Italy. J. Dairy Sci. 96:2801-2807.

Sorrentino, E., E. Salimei, M. Succi, D. Gammariello, T. Di Criscio, G. Panfili, and R. Coppola. 2005. Heat treatment of ass's milk, a hypoallergenic food for infancy. Pages 569-574 in Proc. of Technological Innovation and Enhancement of Marginal Products. C. Severini, T. De Pilli, and R. Giuliani, ed. Claudio Grenzi Editore, Foggia, Italy.

Sorrentino, E., P. Tremonte, M. Succi, G. Pannella, L. Tipaldi, L. Maiuro, and R. Coppola. 2012. Latte crudo tra mito e realtà. Page 134 in Proc. of 40th Congresso Nazionale della Società Italiana di Microbiologia. Accessed Mar. 26, 2014. http://www.societasim. org/immagini/40_sim/riassunti_sim_2012.pdf.

UNI EN ISO (Ente Nacionale Italiano di Unificazione-International Organization for Standardization). 2004. Microbiologia di alimenti e mangimi per animali-Metodo orizzontale per la conta di microrganismi-Tecnica della conta delle colonie a $30^{\circ} \mathrm{C}$. UNI EN ISO 4833:2004. UNI, Milan, Italy.

Waser, M., K. B. Michels, C. Bieli, H. Flöistrup, G. Pershagen, E. von Mutius, M. Ege, J. Riedler, D. Schram-Bijkerk, B. Brunekreef, M. van Hage, R. Lauener, and C. Braun-Fahrländer., and the PARSIFAL Study team. 2007. Inverse association of farm milk consumption with asthma and allergy in rural and suburban populations across Europe. Clin. Exp. Allergy 37:661-670. 